Geopolítica(s) Revista de estudios sobre espacio y poder ISSN: 2172-3958

https://dx.doi.org/10.5209/geop.69163

\title{
COVID-19 Pandemic in Japan: Containment Failed or Successful?
}

\author{
Takashi Yamazaki ${ }^{1}$
}

Recibido: 16 de abril de 2020 / Aceptado: 10 de mayo de 2020

\begin{abstract}
This short article examines key governmental measures against the spread of COVID-19 in Japan from a geopolitical perspective. "Geopolitical" in this article means to see the measures as spatial strategies. At the stage of globalized pandemic, state territoriality or border control is no longer able to effectively control the spread of the virus. Instead, this article argues, multi-scalar intergovernmental coordination is inevitable to tackle the virus moving along increasing trans-border/local human flows. Using the case of Japan, this article overviews how effective social distancing as a spatial strategy has been and illustrates how the limits to such a strategy to control human behavior can affect anti-virus measures. In conclusion, this article argues that the effective devolution of state power to local governments and the strengthening of state supplementary function to sustain local healthcare system and economy would be more desirable than the authoritative concentration of state power in the state of emergency.
\end{abstract}

Keywords: COVID-19 pandemic; Japan; containment; territoriality; intergovernmental coordination.

\section{[es] La pandemia de COVID-19 en Japón: ¿contención fallida o exitosa?}

Resumen. Este breve artículo examina medidas gubernamentales clave contra la propagación del COVID-19 en Japón desde una perspectiva geopolítica. "Geopolítico" en este artículo significa ver las medidas como estrategias espaciales. En la etapa de la pandemia globalizada, la territorialidad estatal o el control fronterizo ya no pueden controlar de manera efectiva la propagación del virus. En cambio, este artículo argumenta que la coordinación intergubernamental multiescalar es inevitable para abordar un virus que se mueve a lo largo de crecientes flujos humanos transfronterizos / locales. Usando el caso de Japón, este artículo examina cuán efectivo ha sido el distanciamiento social como estrategia espacial e ilustra cómo los límites de dicha estrategia para controlar el comportamiento humano pueden afectar las medidas antivirus. En conclusión, este artículo argumenta que la devolución efectiva del poder estatal a los gobiernos locales y el fortalecimiento de la función suplementaria estatal para sostener el sistema de salud y la economía locales sería más deseable que la concentración autorizada del poder estatal en el estado de emergencia.

Palabras clave: pandemia de COVID-19; Japón; contención; territorialidad; coordinación intergubernamental.

1 Professor, Department of Geography, Osaka City University (Japan).

E-mail: yamataka@lit.osaka-cu.ac.jp 


\section{[pt] A pandemia da COVID-19 no Japão: contenção fracassada ou bem- sucedida?}

Resumo. Este pequeno artigo examina as principais medidas governamentais contra a disseminação
do COVID-19 no Japão, de uma perspetiva geopolítica. "Geopolítico" neste artigo significa visualizar
as medidas como estratégias espaciais. No estágio da pandemia globalizada, a territorialidade estatal
ou o controle de fronteiras não podem mais controlar efetivamente a propagação do vírus. Em vez
disso, este artigo argumenta que a coordenação intergovernamental em várias escalas é inevitável no
combate a um vírus que se move ao longo do aumento dos fluxos humanos locais / transfronteiriços.
Usando o caso do Japão, este artigo examina a eficácia do distanciamento social como estratégia
espacial e ilustra como os limites dessa estratégia para controlar o comportamento humano podem
afetar as medidas de antivírus. Em conclusão, este artigo argumenta que a devolução efetiva do poder
do estado aos governos locais e o fortalecimento da função suplementar do estado para sustentar o
sistema de saúde e a economia locais seriam mais desejáveis do que a concentração autorizada do
poder do estado no estado. emergência. Palavras-chave: pandemia da COVID-19; Japão; contenção; territorialidade; coordenação intergovernamental.

Sumario. Introduction. 1. Lessons taken/not taken. 2. COVID-19 in Japan. 3. Territoriality still matters or failed? Conclusion. References.

Cómo citar: Yamazaki, T. (2020). COVID-19 pandemic in Japan: containment failed or successful? Geopolítica(s). Revista de estudios sobre espacio y poder, 11(Especial), 81-91.

\section{Introduction}

It is still too early to make a comprehensive assessment on the spread of COVID19 in Japan. Since the first case of infection was confirmed in mid-January 2020, the national and local (prefecture) governments have implemented several key measures against the outbreak of the virus (Suzuki, 2020). This short article examines these measures from a geopolitical perspective. By "geopolitical" this article refers to governmental policies to control the spatial spread of COVID-19. In order to contain the spread, the spatial behavior of - the physical contacts betweeninfected and non-infected people needs to be controlled. Without any vaccine for the virus at this moment, a main focus of anti-virus measures needs to be placed on the control of human behavior at various spatial scales.

At the stage of globalized pandemic, state territoriality or border control is no longer able to effectively control the spread of the virus. Instead, this article argues, multi-scalar intergovernmental coordination is inevitable to tackle the virus moving along increasing trans-border/local human flows. By looking at the case of Japan, this article overviews how effective social distancing as a spatial strategy has been and illustrates how the limits to such a strategy can affect anti-virus measures. Finally, this article concludes that an effective devolution of state power to local governments and the strengthening of state supplementary function to sustain local healthcare system and economy would be more desirable than the authoritative concentration of state power in the time of emergency. At the end of the article, some concerns and prospects for a coming post-COVID-19 society are presented. 


\section{Lessons taken/not taken}

In my first textbook published in 2010 (Yamazaki, 2010), I referred to the global spread of the 2003 SARS and the 2009 novel influenza (H1N1) to illustrate the effect of Japan's state territoriality or border control. One of the measures the Japanese government employed on these two occasions was strict quarantines (thermometry) at airports against visitors and returnees from overseas infected regions (e.g. China or North America). In the SARS case, although nobody was infected within Japan, a Taiwanese doctor who had visited Japan developed the disease after he returned to Taiwan. Japan's Ministry of Health, Labor and Welfare immediately released the detailed information about the entire route of his travel and the places he visited. The transportation and other facilities he used were thoroughly sanitized. Such governmental reactions caused the cancellation of travels to and reservations of hotels at places where he visited. At the same time, international travel to the infected regions was self-restrained and many international conferences planned to be held in Japan were postponed or cancelled. These reactions have an effect that possible visitors from the infected regions were excluded from the territorial space of Japan.

The H1N1 case induced similar governmental and social reactions. As infection cases increased in Japan, the media sensationally reported strict quarantine at airports and each case of suspected infection. When it was reported that high-school students were infected during their school trip to Canada, their school was exposed to harsh criticism by the public. The disease rapidly spread nationwide and prompted many schools to be closed in fear of infection although the virus tuned out to be attenuated and caused less serious health problems. The H1N1 case also illustrated how Japanese society treated a novel epidemic as coming from outside Japan.

Clearly the globalization of human flows promoted these incidents. It is understandable that Japan as an island state first employed an "edge of water" policy to filter and control the flows at its state borders (mainly airports). Given an incubation period, however, such a territorial policy has obvious limits in preventing a novel virus from entering Japan. Once the virus crosses a state border, the spread of the virus becomes a multi-scalar phenomenon ranging from the local to the global scales and vice versa. The territorial policy, however, has an ideological effect to make people believe that the territorial space of a state can be kept safe. This effect comes from the function of a nation-state as a scale of ideology (Flint \& Taylor, 2011) and constitutes an epistemology called a territorial trap (Agnew, 1994). In an era of globalization, it is unrealistic to believe that the infected external world can be separated from the non-infected internal space of a state. This ideological effect seems to have hindered the formation of effective domestic policies against the spread of a novel virus within Japan compared to its well-established crisis control in the time of natural disasters.

The important lesson taken from the H1N1 case led to the legislation of the Act on Special Measures Concerning Countermeasures against Novel Influenza and Other Diseases (hereafter Anti-H1N1 Act) in 2012. Reflecting on the confusions caused by the H1N1 outbreak, the Japanese government enacted the Act to secure its healthcare system and clarify the legal authorities of prefecture governors in the case of novel virus outbreak. The Act provides inter-governmental coordination 
between national, prefecture, and municipal governments. The territorial assumption of the Act is clearly multi-scaler and not based on a single scalar measure such as border/migration control. Article 45 of the Act grants prefecture governors an authority to control the behavior of people in their prefecture to prevent novel virus outbreak (without any compensation for the economic losses caused by the exercise of this provision). The Article provides that prefecture governors are able to request people not to go out (Paragraph 1), request managers of facilities/events for education, social welfare, and entertainment to close/cancel them (Paragraph 2), instruct $^{2}$ those who refuse the request to accept it (Paragraph 3), and make public the requests made for Paragraphs 2 and 3 immediately (Paragraph 4). According to the Act, therefore, anti-virus measures should be coordinated among the three tiers of government with a prefecture governor (and government) at the center of this inter-governmental coordination.

In my textbook mentioned above, I pointed out the limit of state territoriality against a globalizing novel epidemic and criticized an "edge of water" policy as being ideological. One of my students responded to this passage by saying "I believe the policy is still effective to protect people in Japan." I wondered what made her believe so and why she could believe she was protected. This response made me add the following passage when I revised the textbook in 2013 (Yamazaki, 2013):

It is undoubtedly important to maintain quarantine at state border. However, it is impossible to control all kinds of flows only with state border. It would be more practical to implement multi-scalar policies to combine preventive and symptomatic domestic measures at multiple scales of municipality, workplace, school, neighborhood, home, and body. (p.131).

Seven years later, Japan is exposed to a crisis unprecedented in people's memory. As I foresaw in my revised textbook, multi-scalar measures against COVID-19 are being implemented nationwide by the public and private sectors and people themselves.

\section{COVID-19 in Japan}

The first COVID-19 patient (a Chinese national) in Japan was confirmed on January 14, 2020. He came back from Wuhan, China in early January. The first wave of outbreak was brought about mostly by returnees and travelers from the same place in China. As in the previous cases, Japan first employed an "edge of water" policy to filter and control human flows from Wuhan, which was too late because the secondary infection from Chinese tourists visiting Japan to Japanese had already started (particularly in Hokkaido as their destination). Responding to a constant increase in infection cases and their spread in February, Prime Minister Shinzo Abe requested the nationwide closure of public elementary and junior high schools from March 2, followed by the closure of public high schools and other public facilities

\footnotetext{
2 In this Paragraph, "instruct" (shiji) is used as a more coercive term than "request" (yōsel).
} 
such as libraries, gymnasiums, and museums. Although school children are neither spreaders nor a high-risk group, the Japanese government attempted to minimize the possibility of outbreak without harming the state economy (i.e. the activities of adults).

Fortunately, the Japanese government had already enacted the above-mentioned Anti-H1N1 Act and quickly modified it for COVID-19 in mid-March. Any incident of infection takes place at the local scale (e.g. live music clubs, sports gyms, drinking bars, hospitals, etc.). This general aspect promoted local (prefecture) initiatives earlier than national measures as seen in Hokkaido and Wakayama Prefectures. However, local authorities and agents, particularly hospitals, are not necessarily well equipped with resources essential for increasing infection cases. Continuing restrictions on business, tourism, and event holding have been weakening national and local economies. The Japanese government's supports and compensations for these shortages and losses are still not enough although the spread of infection has just begun to slow down (as of May 4). This has been the most concerning element for Japanese society.

Figure 1. Cumulative confirmed cases of COVID-19 by country (as of 27 April 2020)

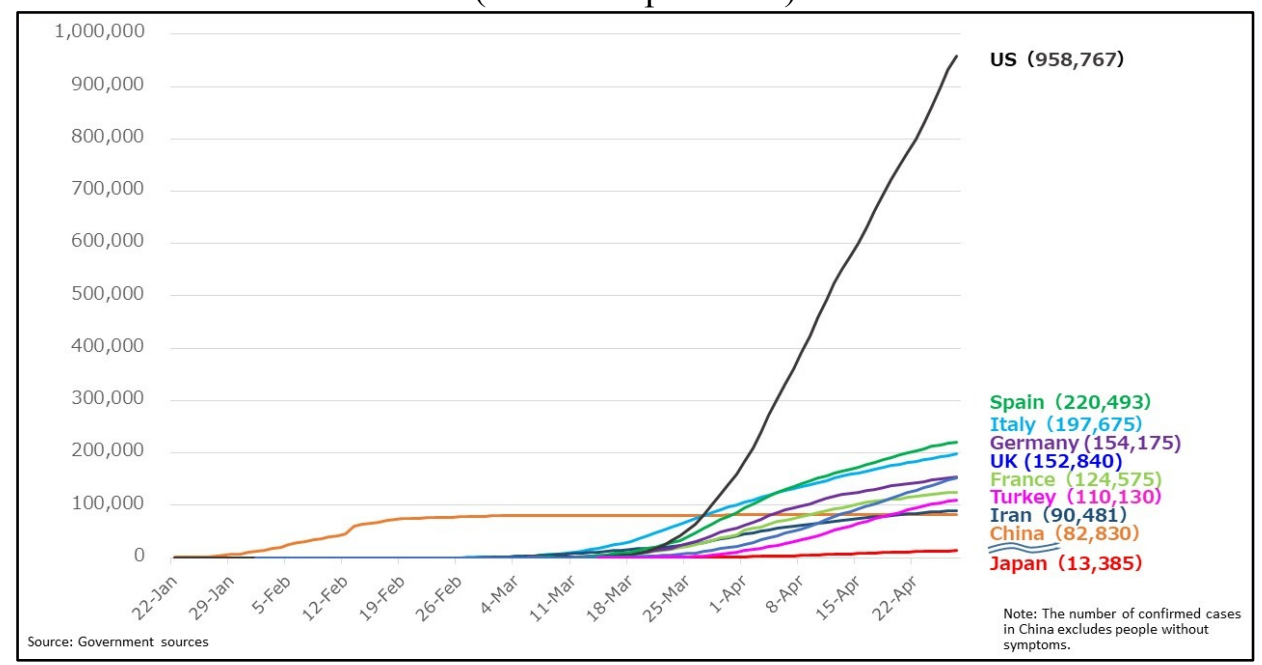

Source: Prime Minister and His Cabinet (2020b).

On the other hand, the level of infection (and death) cases in Japan has been significantly low compared to Europe and the US where an exponential growth of infection appeared earlier (Figure 1). This has been realized without highly strict regulations such as lockdowns and curfews. There are various theories to explain this: limited PCR testing to prevent the collapse of healthcare system, infectioncluster based measures, early stage social distancing, the custom of wearing a mask for preventive purposes, and no tradition of shaking hands, kissing, and hugging (Boyd, 2020; Margolis, 2020; Suzuki, 2020). Nevertheless, the growth of infection has been accelerating and became nationwide since late March (Figure 2). It is reported that this second wave of outbreak was caused by returnees from Europe and the US (National Institute of Infectious Diseases, 2020). 
Figure 2. The trend of the number of confirmed cases

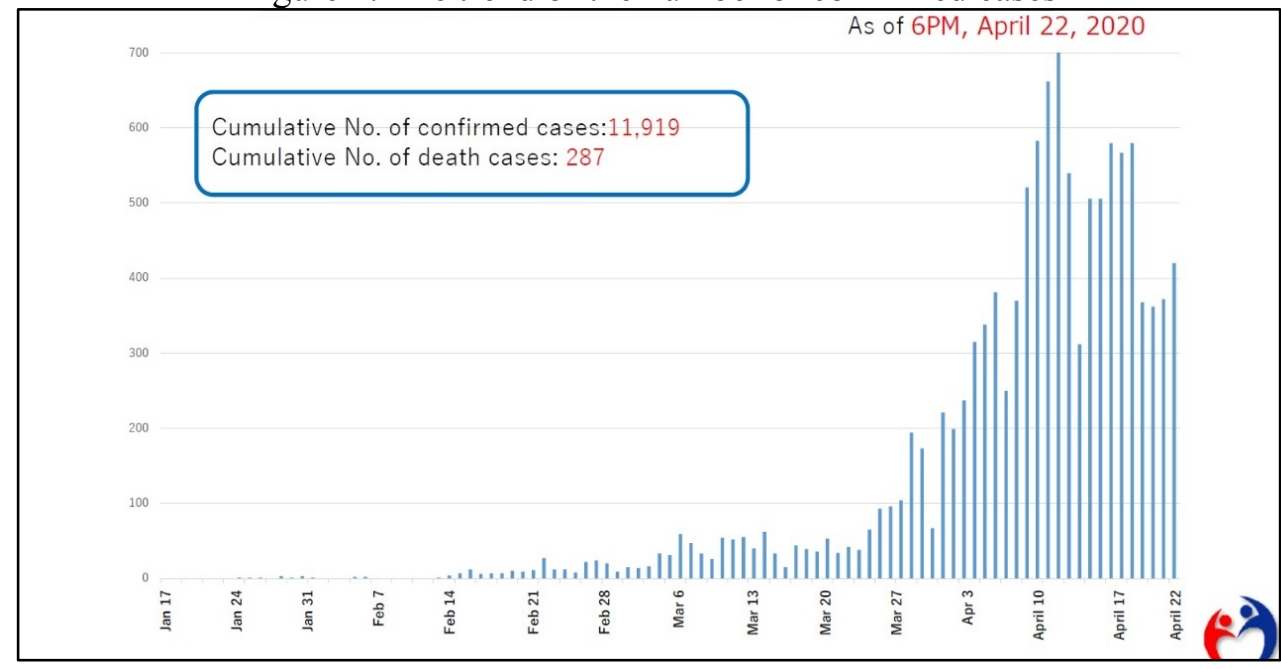

Source: Prime Minister and His Cabinet (2020b).

As the soaring of infection became evident in the metropolitan areas, the Japanese government declared a State of Emergency on April 7. The Declaration based on the Anti-H1N1 Act first covered seven prefectures including the Tokyo and Osaka metropolitan areas. Unlike other countries where strict curfews and radical measures have been employed, the Declaration does not include orders but requests for coordination and cooperation among the public and private sectors. Prime Minister Abe explained the intent of the Declaration (Prime Minister and His Cabinet, 2020a):

This declaration of a state of emergency does not in any way intend to close cities or a lockdown as we are seeing take place overseas. I state that clearly. Trains, buses, and other forms of public transportation will continue to operate. We will under no circumstances particularly block off roads, and in the view of the experts, there is no need whatsoever for such measures. Overseas, when cities were put under lockdown, there were some places where a large number of people slipped out of the cities, resulting in havoc and a spread of infection.

The Declaration has no penalties to impose on its refusers. No police or military forces have been used to enforce national and local measures based on the Declaration. What is seen on the media and street every day is that cabinet ministers, governors, mayors, and local government officials repeatedly request people to voluntarily follow the measures. While it seems that Japan's anti-virus measures have worked so far (Suzuki 2020), there are critical views in the international press on the effect of the moderate Declaration (Rich, Ueno, and Inoue 2020, see also Jiji.com, 2020). 


\section{Territoriality still matters or failed?}

As mentioned above, state territoriality as border control is only one of the possible measures countering the spread of a novel epidemic and is probably effective for a limited time (e.g. before virus spread from outside a state). This, however, does not mean that territoriality at a different scale is ineffective as a spatial anti-virus strategy. According to Sack (1986), territoriality is a spatial strategy to influence social relations using a demarcated space (i.e. territory). Such a strategy can be employed for an infectious disease as a means of social distancing or other coercive measures (for venereal disease and overseas US military bases, see Yamazaki, 2011). The exercise of territoriality involves the relationship between the controlling and the controlled over the use of space, meaning that the existence of a territory is a manifestation of power based on the space.

Thus, closures, blockades, off-limits, curfews, containments, and lockdowns are coercive measures by the powerful to control - exclude, include, transfer, etc.human behavior. These measures may violate individual (human) rights but may be justified by their collective objectives or public utilities. Such justifiability needs to be proved by the anticipated results or effects. Otherwise, rights or even lives of the controlled might be seriously jeopardized. This leads to a normative conclusion that territoriality be exercised in a right place and time and in a right way according to the socio-cultural norms involved.

In the case of Japan, spatial strategies to contain or restrain infection (e.g. public facility or business closure, request not to go out, and other ways for social distancing) do not seem to have been executed in a right place and time and in a right way. This has so far resulted in an increase in and spread of infection cases. Ineffective spatial strategies are not understood as legitimate crisis control, leading to criticisms for infringing on private rights. Compared to Europe and the US, Japan seems to be careful of the infringement of private rights or afraid of its negative impact on economy (Rich, Ueno, and Inoue, 2020, see also the poll results by Gallup International Association, 2020). Although Japanese society has been considered more authoritarian than the western counterparts, Japan's way of exercising spatial strategies seems less strict. This may also be related to the initial reluctance of the national government to compensate economic losses caused by stricter business regulations.

Spatial strategies to control human behavior have geographical spill-over effects as seen in crime prevention with a CCTV camera. One of the effects is positive; the adoption of an effective strategy spreads and covers a wider area. The other is negative; the target subject of the strategy may move (transfer) to other areas not covered by the strategy. Regarding the moderate Declaration, while it may be successful in that it has induced cooperative reactions from local governments, businesses, and people, it has failed to contain the spread of infection in some cases. In order to spatially contain infection, it is necessary to prevent the transfer of the infected. Most troublesome features of the coronavirus include its relatively long incubation period and mild and asymptomatic spreaders. People can be careful of being infected and of infecting if they have clear symptoms. This is not necessarily the case with those infected with the virus. It takes some time for them to realize that they can infect others and change their behavior accordingly. Therefore, in conjunction with moderate countermeasures, these features of the virus infection and the time 
lag caused by them generate the spatial transfer of infection (i.e. failed containment). I explain four cases of failed containment below.

Case 1: travelling and infected abroad

Ministry of Foreign Affairs of Japan raised the COVID-19-related Travel Advice \& Warning on Infectious Diseases to Level 2 (Avoid non-essential travel) for the entire world on March 26. Before the end of March, it seems that some Japanese who had traveled or stayed in Europe and the US returned infected. This inflow of Japanese tourists is thought to have caused the second wave of outbreak (National Institute Infectious Diseases 2020). The danger of travelling abroad except to some hardest-hit countries were neither announced earlier nor recognized well so that the transfer of tourists from Japan-then suppressing the first wave of outbreak-brought the virus back to Japan.

Case 2: lack of effective inter-prefectural coordination

On March 19, Governor of Osaka Prefecture Hirofumi Yoshimura requested people in the prefecture not to move between neighboring Hyogo Prefecture and Osaka during the coming long weekend (March 20 to 22). He made this request according to an informal warning advise from the Anti-COVID-19 Expert Panel for the national government. The actual advice, however, stated that it was recommended to restrict people's movement not only between the two prefectures but also between the two prefectures and other neighboring prefectures (i.e. simply inter-prefectural movement) because there was an increasing trend of infection in the two prefectures. He did not properly understand but mispresented the real intentions of the advice. According to the transportation survey conducted during the long weekend, the volume of inter-prefectural traffic between the two prefectures was reduced only by $5 \%$ compared to the previous weekend (Nihon Keizai Shimbun, 2020). On the contrary, prefectures in the Tokyo metropolitan area issued better coordinated requests according to a similar advice from the Panel.

Case 3: evacuation from the infected areas

The April 7 Declaration covered seven prefectures including the Tokyo and Osaka metropolitan areas where an outbreak would have been anticipated without any intervention. However, some of the prefectures which were not covered began to declare a state of emergency on their own as the spread of infection became accelerating nationwide. On April 16, the Japanese government extended the application of the Declaration to the entire state and designated six new and the original seven prefectures as Special Warning Prefectures. As a reason for this expansion, the Novel Coronavirus Epidemic Countermeasures Headquarters in the national government states "For prefectures other than these Special Warning Prefectures, infection clusters have emerged in non-urban areas due to people's movement from urban areas and a tendency towards outbreak can be seen" (Novel Coronavirus Epidemic Countermeasures Headquarters, 2020: 5). The movement this statement refers to is tourist and homecoming outflow from the original seven prefectures (Matsuzawa, 2020). This is also a transfer of those who should have been contained within where they live (e.g. asymptomatic spreaders). This type of transfer is called "Corona evacuation." In 
order to control this transfer, nationwide inter-prefectural coordination would be necessary.

Case 4: clusters after clusters

Japan's anti-virus measures have focused on infection clusters. In order to prevent Japan's healthcare system from collapsing, efforts have been made to do extensive contact tracing and identify infection clusters. Such clusters have been identified in live music clubs, sports gyms, roofed pleasure boats, buffet-style restaurants, etc. The national and local governments have repeatedly emphasized that people should avoid the "three C's" - Closed spaces where Crowds meet in Close proximity. According to these criteria, local governments have requested cancellations and closures, and local businesses and people have voluntarily accepted these requests. This, however, has become an endless process to chase transfers (i.e. clusters after clusters). Daytime restrictions transferred businesspersons to nighttime drinking bars. Containing families in their house for a long time transferred them to nearby parks for a short break. Shopping centers also became congested with families. The recent incidents exemplify this chain of transfers. Although several prefecture governors requested pachinko parlors ${ }^{3}$ to close their business temporarily, some neglected this request for their survival, leading the governors to make their names public according to the Anti-H1N1 Act. As a result, many customers, some of whom were even from other prefectures, crowded to the parlors remaining open. While this is partially a matter of addiction, the fundamental problem of this transfer is a lack of legal penalty and appropriate economic compensation for business closure.

Given obvious limits to controlling human behavior nationwide, the occurrence of a chain of transfers is inevitable. In order to make social distancing as a spatial strategy more effective in Japan, it would be necessary to complement the strategy with further spatial and non-spatial measures such as airport quarantine, interprefectural coordination, restriction on domestic travel, legal penalty, and economic compensation.

\section{Conclusion}

Nationwide public-school closure in March was a direct request from the national government, which was a wake-up call for local anti-virus initiatives that have continued to date. Since a State of Emergency was declared in early April, prefecture governors and governments have become major players in implementing spatial and non-spatial anti-virus measures. As mentioned above, while social distancing as a spatial strategy has been effective to suppress the spread of infection, the occurrence of a chain of transfers has shown obvious limits to controlling human behavior nationwide. This situation makes it necessary to complement the strategy with further spatial and non-spatial measures. Under the State of Emergency based on the Anti-H1N1 Act, prefecture governors have a power to implement local anti-

\footnotetext{
3 "Pachinko" is a Japanese gambling game played on a vertical pinball machine.
} 
virus measures. The Act, however, doesn't provide any penalties for refusers. Neither does the current national economic compensation for business closures give enough incentives for business owners and workers to follow governmental requests.

Current financial differences among prefectures are reflected on the level of their economic compensation for business closures. After the Declaration covered the entire state on April 16, regional differences in infection, anti-infection measure, and medical capacity have become important factors conditioning local initiatives under the Declaration. These factors are essential to counter the geographically differentiated spread of infection. Non-metropolitan prefectures are not necessarily equipped with high-level medical infrastructure. An exponential growth of infection in such areas would hasten the collapse of healthcare system and increase death toll. It can be concluded from this that not only an effective devolution of state power to local governments but also the strengthening of state supplementary function to sustain local healthcare system and economy would be more desirable than the authoritative concentration of state power in the state of emergency.

Another concern needs to be mentioned before concluding this article. Repeated requests of behavior change for social distancing can affect individual consciousness. People cannot help self-realizing the fear of infection at the scale of their body. The internalization of such fear may make people more susceptible to police state, surveillance society, and the homogenization of social values as well as restrictions on individual/human rights in post-COVID-19 society. There are also growing voices for an amendment of the Japanese Constitution so that the national government can deal more effectively with possible states of emergency. Renewed local autonomy and people's voluntary activities to reconnect society might thus be work as a vaccine to these symptoms.

\section{References}

Agnew, J. (1994). The territorial trap: the geographical assumptions of international relations theory. Review of International Political Economy, 1(1), 53-80.

Boyd, O. (2020). Why is Japan still a coronavirus outlier? The Japan Times, 21 March. Retrieved from https:/www.japantimes.co.jp/opinion/2020/03/21/commentary/japancommentary/japan-still-coronavirus-outlier/\#.Xq7BNqj7Q2w

Flint, C., \& Taylor, P. (2011). Political Geography: World-Economy, Nation-State, and Locality $\left(6^{\text {th }}\right.$ ed). New York: Routledge.

Gallup International Association. (2020). The coronavirus: a vast scared majority around the world (Snap poll in 28 countries by Gallup International Association). Retrieved from https:/www.gallup-international.com/wpcontent/uploads/2020/03/GIA_SnapPoll_2020_COVID_Tables_final.pdf

Jiji.com. (2020). "Taking a bold measure is too late." "There is no enforcing power." The overseas media commented (in Japanese). Jiji.com, 7 April. Retrieved from https://www.jiji.com/jc/article?k=2020040701087\&g=int

Margolis, E. (2020). "This may be the tip of the iceberg": why Japan's coronavirus crisis may be just beginning. Vox, 28 March. Retrieved from https:/www.vox.com/covid-19coronavirus-explainers/2020/3/28/21196382/japan-coronavirus-cases-covid-19-deathsquarantine 
Matsuzawa, N. (2020). The meaning of a nationwide expansion in the target of the Declaration of a State of Emergency: let's not go back to hometown (in Japanese). NIL Research Institute Researcher's Eyes, 20 April. Retrieved from https://www.nliresearch.co.jp/report/detail $/ \mathrm{id}=64269$ ? $\mathrm{site}=\mathrm{nli}$

National Institute of Infectious Diseases. (2020). Genome molecular epidemiology survey on Novel Coronavirus SARS-CoV-2 (in Japanese). Retrieved from https://www.niid.go.jp/niid/ja/basic-science/467-genome/9586-genome-2020-1.html

Nihon Keizai Shimbun. (2020). The volume of traffic at the intersection of national routes slightly declined by self-restrictions on traffic between Osaka and Hyogo (in Japanese). Nihon Keizai Shimbun, 24 March. Retrieved from https://www.nikkei.com/article/DGXMZO57158640U0A320C2AC8000/

Novel Coronavirus Epidemic Countermeasures Headquarters. (2020). Basic Guidelines for Novel Coronavirus Epidemic Countermeasures (in Japanese). Retrieved from https:/www.mhlw.go.jp/content/10900000/000622473.pdf

Prime Minister and His Cabinet. (2020a). [COVID-19] Press conference by the Prime Minister regarding the Declaration of a State of Emergency. Retrieved from https://japan.kantei.go.jp/98_abe/statement/202004/_00001.html

Prime Minister and His Cabinet. (2020b). [COVID-19] Situation in Japan (Statistical Data). Retrieved from http://japan.kantei.go.jp/ongoingtopics/_00017.html

Rich, M., Ueno, H., \& Inoue, M. (2020). Japan declared a coronavirus emergency. Is it too late? The New York Times, 7 April. Retrieved from https:/www.nytimes.com/2020/04/07/world/asia/japan-coronavirus-emergency.html

Sack, R. D. (1986). Human Territoriality: Its Theory and History. Cambridge: Cambridge University Press.

Suzuki, K. (2020). COVID-19 strategy: the Japan model. The Japan Times, 28 April. Retrieved from https:/www.japantimes.co.jp/opinion/2020/04/28/commentary/japancommentary/covid-19-strategy-japan-model/\#.Xq692qj7Q2w

Yamazaki, T. (2010). Space, Place, and Politics: Towards a Geography of Politics (in Japanese). Kyoto: Nakanishiya.

Yamazaki, T. (2011). The US militarization of a "host" civilian society: the case of postwar Okinawa, Japan. In S. Kirsch and C. Flint (Eds.), Reconstructing Conflict: Integrating War and Post-War Geographies (pp.253-272). Surrey: Ashgate.

Yamazaki, T. (2013). Space, Place, and Politics: Towards a Geography of Politics (2 ${ }^{\text {nd }}$ ed). (in Japanese). Kyoto: Nakanishiya. 